\title{
The role of hydrogen peroxide in regulation of plant metabolism and cellular signalling in response to environmental stresses
}

\author{
Ireneusz Ślesak ${ }^{1}$, Marta Libik ${ }^{1}$, Barbara Karpinska², Stanislaw Karpinski ${ }^{1,3 凶}$ and \\ Zbigniew Miszalski ${ }^{1,4 凶}$ \\ ${ }^{1}$ Institute of Plant Physiology, Polish Academy of Sciences, Kraków, Poland; ${ }^{2}$ Faculty of Life Sciences, Universi- \\ ty College of Södertörns, Huddinge, Sweden; ${ }^{3}$ Department of Botany, Stockholm University, Stockholm, Sweden; \\ ${ }^{4}$ Institute of Biology, Pedagogical Academy, Kraków, Poland
}

Received: 30 October, 2006; revised: 29 November, 2006; accepted: 08 February, 2007

available on-line: 27 February, 2007

\begin{abstract}
Hydrogen peroxide $\left(\mathrm{H}_{2} \mathrm{O}_{2}\right)$ is produced predominantly in plant cells during photosynthesis and photorespiration, and to a lesser extent, in respiration processes. It is the most stable of the socalled reactive oxygen species (ROS), and therefore plays a crucial role as a signalling molecule in various physiological processes. Intra- and intercellular levels of $\mathrm{H}_{2} \mathrm{O}_{2}$ increase during environmental stresses. Hydrogen peroxide interacts with thiol-containing proteins and activates different signalling pathways as well as transcription factors, which in turn regulate gene expression and cell-cycle processes. Genetic systems controlling cellular redox homeostasis and $\mathrm{H}_{2} \mathrm{O}_{2}$ signalling are discussed. In addition to photosynthetic and respiratory metabolism, the extracellular matrix (ECM) plays an important role in the generation of $\mathrm{H}_{2} \mathrm{O}_{2}$, which regulates plant growth, development, acclimatory and defence responses. During various environmental stresses the highest levels of $\mathrm{H}_{2} \mathrm{O}_{2}$ are observed in the leaf veins. Most of our knowledge about $\mathrm{H}_{2} \mathrm{O}_{2}$ in plants has been obtained from obligate $\mathrm{C}_{3}$ plants. The potential role of $\mathrm{H}_{2} \mathrm{O}_{2}$ in the photosynthetic mode of carbon assimilation, such as $\mathrm{C}_{4}$ metabolism and CAM (Crassulacean acid metabolism) is discussed. We speculate that early in the evolution of oxygenic photosynthesis on Earth, $\mathrm{H}_{2} \mathrm{O}_{2}$ could have been involved in the evolution of modern photosystem II.
\end{abstract}

Keywords: acclimatory and defence responses, antioxidants, cell wall, cellular metabolism, cellular redox sensors, hormone signalling, photosynthesis, reactive oxygen species (ROS) signalling, transcription factors

\section{INTRODUCTION}

Hydrogen peroxide is well-known as an antiseptic because of its cytotoxic effects on many bacterial strains. It is often used as a disinfectant at wound sites (e.g. Halliwel \& Gutteridge, 1999). The role of $\mathrm{H}_{2} \mathrm{O}_{2}$ in plant biochemistry and physiology, and various functions of $\mathrm{H}_{2} \mathrm{O}_{2}$ in plants have been described in many review papers (Kuźniak \& Ur- banek, 2000; Neill et al., 2002a; 2002b; Apel \& Hirt 2004; Hung et al., 2005).

It is believed that the presence of $\mathrm{O}_{2}$ in the Earth's atmosphere originates from photosynthetic activity. However, oxygen can be viewed as a double-edged molecular sword since it is involved in two very different roles in biological systems: it is a prerequisite for aerobic metabolism and consequent normal growth and development, but at

\footnotetext{
Corresponding authors: Stanislaw Karpinski, Institute of Plant Physiology, Polish Academy of Sciences, Niezapominajek 21, 30-239 Kraków, Poland; phone: (48 12) 425 1833; fax: (48 12) 425 1844; e-mail: Stanislaw.Karpinski@botan.su.se; or Zbigniew Miszalski, phone: (48 12) 425 1833; fax: (48 12) 425 1844; e-mail: z.miszalski@ifr-pan.krakow.pl

Abbreviations: ABA, abscisic acid; APX, ascorbate peroxidase (EC 1.11.1.11); Asc, ascorbate; ECM, extracellular matrix; CAT, catalase (EC 1.11.1.6); EEE, excess excitation energy; GPX, glutathione peroxidase (EC 1.11.1.9); GSH, reduced glutathione; GST, glutathione-S-transferase (EC 2.5.1.18); OEC, oxygen-evolving complex; PET, photosynthetic electron transport; PQ, plastoquinone; PSI, photosystem I; PSII, photosystem II; ROS, reactive oxygen species; RuBisCO, ribulose-1,5bisphosphate carboxylase/oxygenase (EC 4.1.1.39); SA, salicylic acid; SOD, superoxide dismutase (EC 1.15.1.1); TF, transcription factor; TRX, thioredoxin.
} 
the same time the reduction of molecular dioxygen in biological systems very often results in the formation of reactive oxygen species (ROS) that can cause deregulation of normal cellular processes and ultimately cause cell death. Therefore, in plants and in other aerobic organisms antioxidant systems have evolved and different ROS are used as signalling molecules in basic cellular processes. From this context it is very interesting to analyse $\mathrm{H}_{2} \mathrm{O}_{2}$ as one of the major and the most stable ROS that regulates basic acclimatory, defence and developmental processes in plants. It can be suspected that ecological niches for anaerobic organisms were limited in the presence of an increased $\mathrm{O}_{2}$ and ROS level.

A number of different oxygen derivatives are described as ROS, also called AOS (active oxygen species). ROS include mainly the superoxide anion radical $\left(\mathrm{O}_{2}^{--}\right), \mathrm{H}_{2} \mathrm{O}_{2}$, hydroxyl radical ( $\mathrm{HO} \mathrm{O}^{*}$, perhydroxyl radical $\left(\mathrm{HO}_{2}{ }^{\circ}\right)$, and singlet oxygen $\left({ }^{1} \mathrm{O}_{2}\right)$ (Bartosz, 1997; Dat et al., 2000; Halliwell, 2006). Oxygen in the ground state is a molecule with two unpaired electrons each located in a different $\pi^{*}$ anti-bonding orbital, and divalent reduction of $\mathrm{O}_{2}$ is not a simple process and requires the generation of univalent intermediates. The addition of a single electron requires an energy input and reduces $\mathrm{O}_{2}$ to the superoxide anion radical (eqn. 1):

$\mathrm{O}_{2}+1 \mathrm{e} \rightarrow \mathrm{O}_{2}^{-\cdot}$

Since the extra electron is in an unpaired state in the outer orbital, the superoxide is a free radical. It is relatively unstable, being either converted back to $\mathrm{O}_{2}$, or in reaction with a proton, to $\mathrm{H}_{2} \mathrm{O}_{2}$, either spontaneously or in a reaction catalysed by the enzyme superoxide dismutase (SOD) (eqn. 2):

$2 \mathrm{O}_{2}^{-\cdot}+2 \mathrm{H}^{+} \rightarrow \mathrm{H}_{2} \mathrm{O}_{2}+\mathrm{O}_{2}$

In contrast to the superoxide, $\mathrm{H}_{2} \mathrm{O}_{2}$ belongs to non-radical ROS and is a molecule that carries no net charge (Halliwell, 2006). Because of this and the longer half-life of $\mathrm{H}_{2} \mathrm{O}_{2}$ than that of the superoxide anion radical, hydrogen peroxide is more likely to be a long-distance signalling molecule than superoxide (Vranová et al., 2002). Membrane water channels known as aquaporins may facilitate $\mathrm{H}_{2} \mathrm{O}_{2}$ transmembrane movement together with water (Henzler \& Steudel, 2000).

This paper is focused on the role of $\mathrm{H}_{2} \mathrm{O}_{2}$ in the plant cell, but it should be noted that the role of $\mathrm{H}_{2} \mathrm{O}_{2}$ in many physiological processes cannot be separated from that of other ROS and the whole antioxidant response system (Bartosz, 1997; Mittler, 2002). The common feature of ROS is that they easily react with other molecules such as lipids, nucleic acids and proteins, which can be damaging or even fatal for the cell (Inzé \& Van Montagu, 1995; Matés, 2000; Mittler, 2002).

\section{CELLULAR AND EXTRACELLULAR SOURCES OF $\mathrm{H}_{2} \mathrm{O}_{2}$}

Hydrogen peroxide is produced not only through the disproportionation of superoxide (eqn. 2), but also due to the reduction of $\mathrm{O}_{2}^{--}$by a reductant $(\mathrm{X})$ such as ascorbate (Asc), thiols, ferredoxins and others (Asada \& Takahashi, 1987) (eqn. 3):

$\mathrm{O}_{2}^{-\cdot}+\mathrm{H}^{+}+\mathrm{XH}_{2} \rightarrow \mathrm{H}_{2} \mathrm{O}_{2}+\mathrm{XH}$

Thus, hydrogen peroxide cellular levels are strictly linked with the generation of superoxide $\left(\mathrm{O}_{2}^{-*}\right)$. Nevertheless, other oxidases such as glycolate oxidases, glucose oxidases, amino-acid oxidases, and sulfite oxidases release $\mathrm{H}_{2} \mathrm{O}_{2}$ following the oxidation of their respective substrates (Asada \& Takahashi, 1987; Asada, 1999). In recent years other enzymatic sources of $\mathrm{O}_{2}^{-*} / \mathrm{H}_{2} \mathrm{O}_{2}$ such as cell wall-bound peroxidases, oxalate, amine and plasma membrane NADPH oxidases have been identified (Fig. 1; Wojtaszek, 1997; Bolwell et al., 2002; Svedružić et al., 2005). Moreover, many reactions involved in photosynthesis and respiration are responsible for the production of $\mathrm{H}_{2} \mathrm{O}_{2}$. This means that $\mathrm{H}_{2} \mathrm{O}_{2}$ and other ROS are unavoidable by-products of normal aerobic metabolism (e.g. Bartosz et al., 1997; Dat et al., 2000; Mittler, 2002).

\section{Chloroplasts}

The photosynthetic electron transport (PET) chain in the chloroplast is responsible for $\mathrm{H}_{2} \mathrm{O}_{2}$ production. The PET chain includes a number of enzymes on the reducing (acceptor) side of photosystem I (PSI): Fe-S centers, reduced thioredoxin (TRX), and ferredoxin. These electron transport components are auto-oxidizable and under conditions limiting the availability of NADP, superoxide anion radical can be formed (Dat et al., 2000; Foyer \& Noctor, 2000). Mehler (1951) described the photo-reduction of $\mathrm{O}_{2}$ in chloroplasts in vitro and identified $\mathrm{H}_{2} \mathrm{O}_{2}$ as the reaction product. Later, $\mathrm{O}_{2}^{-\cdot}$ was identified as the primary product of $\mathrm{O}_{2}$ photoreduction in thylakoids (Fig. 1; Asada \& Takahashi, 1987). Currently, the so-called 'Mehler reaction' is considered as the primary and the most powerful source of $\mathrm{H}_{2} \mathrm{O}_{2}$ / ROS in chloroplasts, and the rate of $\mathrm{O}_{2}$ photoreduction depends on environmental conditions (Asada \& Takahashi, 1987; Mullineaux \& Karpinski, 2002; Logan et al., 2006). It is widely accepted that the Mehler reaction acts as an alternative sink for an excess of electrons, generated during excess excitation energy (EEE) stress (Karpinski et al., 1999; 2003), and the whole PET chain from water to $\mathrm{O}_{2}$ is known as 'pseudocyclic electron flow' (Asada, 1999; Foyer \& Noctor, 2000). The $\mathrm{H}_{2} \mathrm{O}_{2}$ production in chloroplasts is catalyzed by SOD forms containing in the active site copper/zinc (Cu/Zn-SOD) or iron (Fe-SOD) (for 


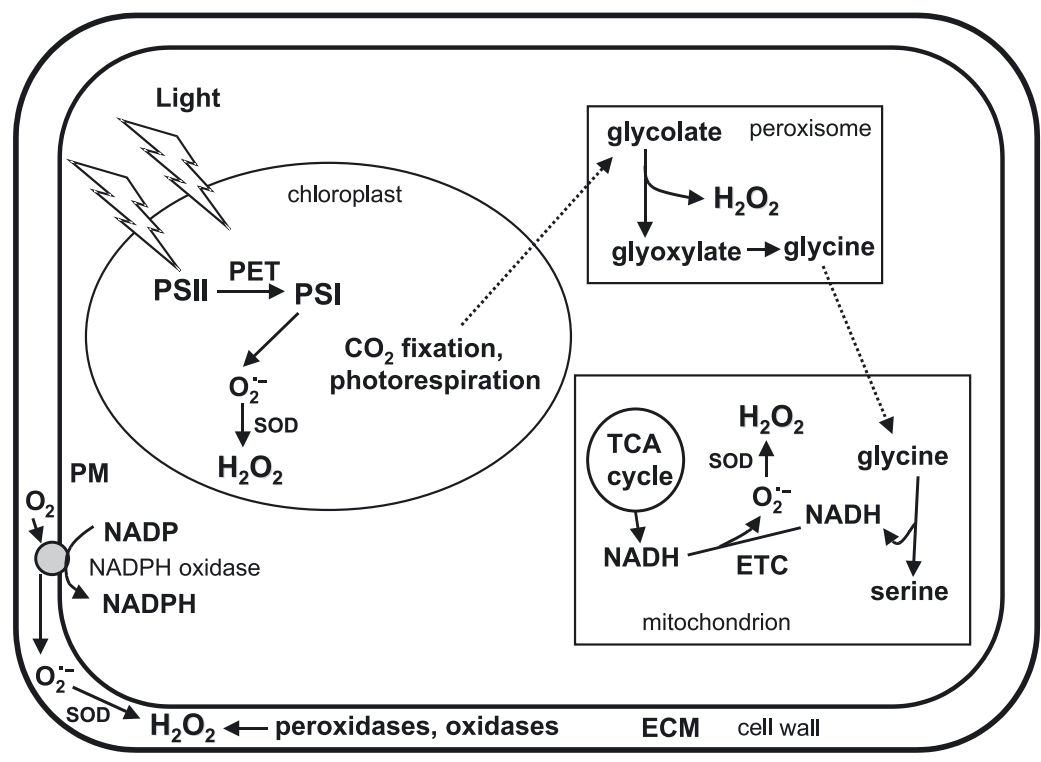

a review see: Alscher et al., 2002). The reduction of $\mathrm{O}_{2}^{-\cdot}$ by ascorbate (Asc) and reduced glutathione (GSH) does not contribute much to the production of $\mathrm{H}_{2} \mathrm{O}_{2}$ in the chloroplast (Asada, 1999). Water oxidation at photosystem II (PSII) and univalent photoreduction of $\mathrm{O}_{2}$ (Mehler reaction) in PSI is coupled to both the production and destruction of $\mathrm{H}_{2} \mathrm{O}_{2}$ by ascorbate peroxidase (APX). The final reaction is the regeneration of ascorbate from monodehydroascorbate (MDHA) by monodehydroascorbate reductase (MDHAR). This transfer of electrons from $\mathrm{H}_{2} \mathrm{O}$ to $\mathrm{H}_{2} \mathrm{O}$ is often called the Mehler-peroxidase cycle (Foyer \& Noctor, 2000) or the water-water cycle. The name denotes that water is the source of electrons at PSII and the final product of the cycle (Asada, 1999). Additionally, partial water oxidation by the manganese-containing, oxygen evolving complex in PSII can also lead to $\mathrm{H}_{2} \mathrm{O}_{2}$ formation (Fine \& Frasch, 1992).

\section{Peroxisomes}

The main function of peroxisomes in the plant cell is photorespiration, which is light-dependent uptake of $\mathrm{O}_{2}$ and the associated release of $\mathrm{CO}_{2}$ connected with the generation of $\mathrm{H}_{2} \mathrm{O}_{2}$ (Fig. 1.; Dat et al., 2000; Wingler et al., 2000). Besides glycolate oxidation, $\mathrm{H}_{2} \mathrm{O}_{2}$ can be generated in the peroxisome e.g. via $\beta$-oxidation of fatty acids and oxidation of other substrates (Dat et al., 2000), but the significance of these processes in $\mathrm{H}_{2} \mathrm{O}_{2}$ production in comparison to glycolate oxidation in $\mathrm{C}_{3}$ plants appears minor (Foyer \& Noctor, 2003). Photorespiration results from the oxygenase activity of ribulose-1,5-bisphosphate carboxylase/oxygenase ( $\mathrm{RuBisCO}$ ), and is associated with increased $\mathrm{H}_{2} \mathrm{O}_{2}$ production in the peroxisome, and supply of glycine for the synthesis of the primary antioxidant glutathione (Noctor et al., 1999). Because of the consumption of reducing power and energy, this apparently wasteful process could in fact act as an electronic valve and ease the electronic burden of the photosynthetic machinery (Kozaki \& Takeba, 1996; Willekens et al., 1997; Wingler et al., 2000; Cornic \& Fresneau, 2002). Because they drain electrons through the PET, the Mehler reaction and photorespiration participate through the redox status of the plastoquinone (PQ) pool in the induction of the APX1 and APX2 genes (Karpinski et al., 1997; 1999). In $C_{3}$ plants exposed to conditions favouring high rates of oxygenation (warm sunny days - EEE conditions), the photorespiratory pathway would appear to be the fastest process for generating $\mathrm{H}_{2} \mathrm{O}_{2}$ (Foyer \& Noctor, 2000).

\section{Mitochondria}

In plant mitochondria superoxide anion radical production occurs mainly at two sites of the electron transport chain: $\mathrm{NAD}(\mathrm{P}) \mathrm{H}$ dehydrogenases (complex I) and the cytochrome $b c_{1}$ complex (complex III) (Møller, 2001). This process results in the formation of $\mathrm{H}_{2} \mathrm{O}_{2}$, primarily through the action of a mitochondrion-specific manganese SOD (Mn-SOD) (Fig. 1; Rhoads et al., 2006). The amount of $\mathrm{H}_{2} \mathrm{O}_{2}$ produced in plant mitochondria is less than that of chloroplasts or peroxisomes when exposed to light (Foyer \& Noctor, 2003), but in the dark or in non-green tissues, mitochondria can be a major source of ROS (Rhoads et al., 2006). Theoretical calculations suggest that mitochondrial $\mathrm{H}_{2} \mathrm{O}_{2} / \mathrm{ROS}$ production probably does not differ between light and dark conditions, since total $\mathrm{O}_{2}$ consumption is less affected by light than by tricarboxylic acid (TCA) cycle activity (Foyer \& Noctor, 2003). The alternative oxidase (AOX) which catalyzes the tetravalent reduction of $\mathrm{O}_{2}$ by ubiquinone can limit $\mathrm{H}_{2} \mathrm{O}_{2} /$ ROS generation (Juszczuk \& Rychter, 2003). The AOX competes with complex III for electrons and thus might help to lower ROS 
production (Apel \& Hirt, 2004). The mitochondrial contribution in $\mathrm{H}_{2} \mathrm{O}_{2}$ generation in plant cells under light conditions requires further study, since photosynthesis and respiration in the light are strongly interdependent (Van Lis \& Atteia, 2004).

\section{Other sources of $\mathrm{H}_{2} \mathrm{O}_{2}$ in the plant cell}

$\mathrm{H}_{2} \mathrm{O}_{2}$ is also produced in the cytoplasm, plasma membrane and in the extracellular matrix (ECM). In the cytoplasm, the electron transport chain associated with the endoplasmic reticulum is the main source of $\mathrm{H}_{2} \mathrm{O}_{2} / \mathrm{ROS}$, where reduced forms of cytochrome P450 and cytochrome P450 reductase that are involved in oxidation and hydroxylation processes, as well as cytochrome $b_{5}$ and cytochrome $b_{5}$ reductase that are engaged in fatty acid desaturation, donate electrons to $\mathrm{O}_{2}$ producing superoxide, and a cytosolic form of SOD can convert $\mathrm{O}_{2}^{--}$to $\mathrm{H}_{2} \mathrm{O}_{2}$ (e.g. Bartosz, 1997; Mittler et al., 2004). The cytosol cannot be regarded as a major source of $\mathrm{H}_{2} \mathrm{O}_{2}$ in plant cells, but it may act as a sink for hydrogen peroxide leaking from other cellular compartments. However, the function of cytosol-generated $\mathrm{H}_{2} \mathrm{O}_{2}$ is not understood.

NADPH oxidase at the plasma membrane in the plant cell is the most intensively studied oxidase system. The NADPH-dependent oxidase system (sometimes referred to as rboh (for respiratory burst oxidase homologue)), similar to that present in mammalian neutrophils, has received the most attention. It catalyzes the production of $\mathrm{O}_{2}^{-\cdot}$ by one-electron reduction of oxygen using NADPH as the electron donor (Desikan et al., 2003; Mahalingam \& Federoff, 2003; Apel \& Hirt, 2004). The superoxide anion radical is most likely located in the apoplastic space and is converted either spontaneously or by extracellular SOD to $\mathrm{H}_{2} \mathrm{O}_{2}$ (Fig. 1; Karpinska et al., 2001; Bolwell et al., 2002). Genes for NADPH oxidase or rboh genes have been cloned from several plant species (Desikan et al., 2003). It should be noted that the ECM in higher plants is composed of cellulose, hemicelluloses, pectins, lignins and protein-based fiber matrices and also contains $\mathrm{H}_{2} \mathrm{O}_{2}$ producing/removing enzymes. For this reason, in addition to NADPH oxidase, many enzymes of ECM, such as: pH-dependent cell wall peroxidases, germins, germinlike oxalate oxidases, and amine oxidases have been proposed as sources of $\mathrm{H}_{2} \mathrm{O}_{2}$ in the apoplast (Lane, 1994; Bolwell et al., 2002; Kacperska, 2004). Therefore, the role of hydrogen peroxide and other ROS in ECM should not only be limited to defense responses, but their primary role is in the regulation of the synthesis of cell wall components, e.g. lignin (Olson \& Varner, 1993; Wojtaszek, 1997; Ros Barceló, 1998).

\section{REMOVAL OF $\mathrm{H}_{2} \mathrm{O}_{2}$}

Elimination of $\mathrm{H}_{2} \mathrm{O}_{2}$ is connected with scavenging of other ROS and the steady state level of cellular $\mathrm{H}_{2} \mathrm{O}_{2}$ depends on the redox status of the cell (e.g. Karpinski et al., 2003; Mateo et al., 2006). In plant cells both $\mathrm{H}_{2} \mathrm{O}_{2}$ production and removal processes are precisely regulated and co-ordinated in the same or in different cellular compartments. The mechanisms of $\mathrm{H}_{2} \mathrm{O}_{2}$ scavenging are regulated by both non-enzymatic and enzymatic antioxidants.

\section{Low molecular mass antioxidants}

To complement the dissipation mechanisms mentioned above and to counter-act the oxidative pressure imposed by $\mathrm{H}_{2} \mathrm{O}_{2} / \mathrm{ROS}$ formation, plants have a multi-level antioxidant system, consisting of antioxidants, such as: Asc, $\alpha$-tocopherol and GSH as well as a multitude of ROS scavenging enzymes (Apel \& Hirt, 2004). Ascorbate (vitamin C) has been shown to react not only with $\mathrm{H}_{2} \mathrm{O}_{2}$, but also with $\mathrm{O}_{2}^{-*}, \mathrm{HO}^{-}$, and lipid peroxides (Smirnoff, 1996; Noctor \& Foyer, 1998). It is also involved as a co-factor in the reaction catalysed by violaxanthine de-epoxidase of the xanthophyll cycle (Demmig-Adams \& Adams, 1996). Tocopherol (vitamin E) is a lipid-soluble antioxidant capable of bringing to an end the free radical reactions that cause lipid peroxidation. Reduced glutathione (GSH) can react directly with ROS to detoxify them or can scavenge peroxides as a cofactor of glutathione peroxidases (GPXs). Moreover, GSH is used to regenerate oxidised ascorbate and tocopherol and oxidised-SH groups of proteins (Noctor \& Foyer, 1998; Mullineaux et al., 2000). Since glutathione is present in plant cells in millimolar concentrations, it is regarded as the key determinant of the cellular redox state (Creissen et al., 1999; Pastori \& Foyer, 2002). Glutathione levels, redox status and biosynthesis can regulate the expression of a large number of genes, among them components of the antioxidant defence system and the pathogen related 1 (PR1) gene (Ball et al., 2004; Mateo et al., 2006).

\section{Enzymatic antioxidant system}

Ascorbate and glutathione are also used as cofactors in reactions catalyzed by peroxidases (APX and GPX) to reduce $\mathrm{H}_{2} \mathrm{O}_{2}$ to water. Expression of genes for the cytosolic APX1 and APX2 is controlled, at least in part, at the chloroplast level. The activity of APXs is thought to form a second barrier of defence against $\mathrm{H}_{2} \mathrm{O}_{2} / \mathrm{ROS}$ produced in the chloroplasts (Karpinski et al., 1997; 1999; Karpinska et al., 2000; Fryer et al., 2003; Chang et al., 2004). The role of GPXs as an $\mathrm{H}_{2} \mathrm{O}_{2}$ scavenger 
has received modest attention (Mullineaux et al., 1998). Superoxide dismutases convert $\mathrm{O}_{2}^{--}$to $\mathrm{H}_{2} \mathrm{O}_{2}$ (eqn. 2) and thus form a crucial part of the cellular antioxidant response system. The various SOD forms are induced with different kinetics during sustained stress conditions (Alscher et al., 2002). Oxidised glutathione (GSSG) is regenerated by glutathione reductase (GR) in a NADPH-consuming reaction (Edwards et al., 1994; Winglse \& Karpinski, 1996). Glutathione reductase completes the ascorbate-glutathione cycle by regenerating the glutathione pool with NADPH as the electron donor (Apel \& Hirt, 2004). Glutathione-S-transferase (GST) catalyses the conjugation of GSH to a variety of molecules and thus marks them for secretion. GSTs detoxify breakdown products of lipid peroxides. They are induced inter alia by ROS and pathogen attack stresses (Dixon \& Lamb, 1990; Dixon et al., 2002). Apart from the peroxidases (APX and GPX) also a group of enzymes collectively called peroxiredoxins are able to reduce $\mathrm{H}_{2} \mathrm{O}_{2}$ and many other diverse peroxides (Horling et al., 2002). Catalase (CAT) is another key enzyme responsible for $\mathrm{H}_{2} \mathrm{O}_{2}$ decomposition (Apel \& Hirt, 2004). In Arabidopsis, CAT is encoded by a multi-gene family consisting of three genes (CAT1, CAT2, CAT3) encoding individual subunits that associate to form at least six isoenzymes (Frugoli et al., 1996). The steady state levels of catalase mRNA, protein synthesis and activity are tightly regulated in a number of plant species. Furthermore, peroxisomal catalase has been suggested to be photosensitive (Feierabend et al., 1992; Hertwig et al., 1992; Schmidt et al., 2002). Recently, a genetic system that controls $\mathrm{H}_{2} \mathrm{O}_{2}$ levels with the involvement of CAT has been identified and described in Arabidopsis (Mateo et al., 2004).

\section{$\mathrm{H}_{2} \mathrm{O}_{2}$ IN STRESS CONDITIONS AND AS A SIGNALLING MOLECULE}

It is well-documented that $\mathrm{H}_{2} \mathrm{O}_{2}$ plays a central role in responses to both abiotic and biotic stresses in plants. This molecule seems to be a "master hormone" that controls a variety of stress responses and physiological adjustments (Fig. 2), including the ROS/hormonal homeostasis in the cell. Many studies have reported increases in $\mathrm{H}_{2} \mathrm{O}_{2}$ concentration after exposure to stress (for a review see: Neill et al., 2002a; Kacperska, 2004). The rate of $\mathrm{H}_{2} \mathrm{O}_{2}$ production depends on the strength and duration of the imposed stress. Moreover, $\mathrm{H}_{2} \mathrm{O}_{2}$ levels differ in various cell compartments and these levels are related to the type of stress, e.g. excess light stress is responsible for the overproduction of $\mathrm{H}_{2} \mathrm{O}_{2}$ mainly in the chloroplast (Karpinski et al., 1999; Karpinska et al., 2000; Ślesak et al., 2003).

In contrast to animal cells, plants seem to be much more resistant to high concentrations of $\mathrm{H}_{2} \mathrm{O}_{2}$. Hydrogen peroxide is toxic for most animal cells at levels of about $10-10^{2} \mu \mathrm{M}$ (Halliwel \& Gutteridge, 1999). Experiments with plant material have demonstrated that plant tissues can tolerate high concentrations of $\mathrm{H}_{2} \mathrm{O}_{2}$ in the range $10^{2}-2 \times 10^{5} \mu \mathrm{M}$. Moreover, plants pre-treated with $\mathrm{H}_{2} \mathrm{O}_{2}$ were more resistant to excess light and chilling stresses (Prasad et al., 1994; Karpinski et al., 1999; Karpinska et al., 2000; Yu et al., 2003). The results of these experiments appear to be largely in disagreement with in vitro experiments concerning inhibition of activity of some enzymes involved in the Calvin cycle at relatively low (10 $\mu \mathrm{M})$ concentrations of $\mathrm{H}_{2} \mathrm{O}_{2}$ (Kaiser, 1979). The problem with the interpretation of these data relates to the actual intracellular $\mathrm{H}_{2} \mathrm{O}_{2}$ steady state concentra-

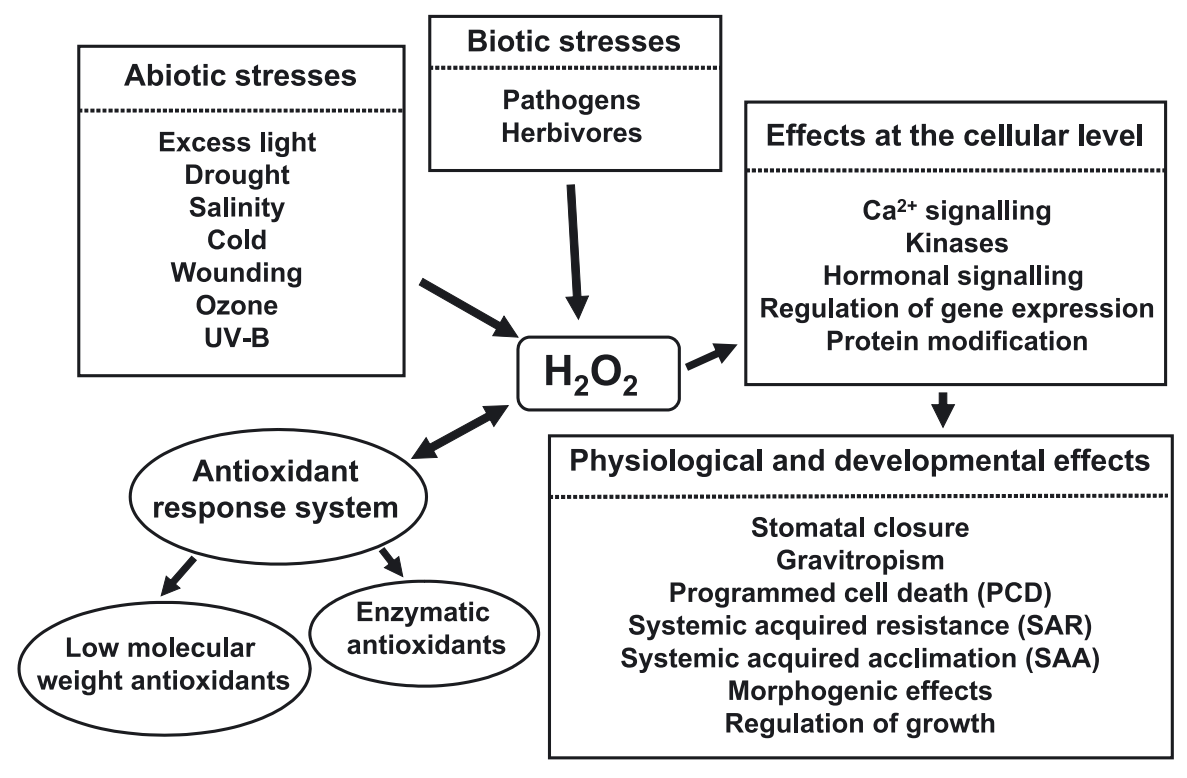

Figure 2. The central role of $\mathrm{H}_{2} \mathrm{O}_{2}$ in plant responses to various environmental stresses.

The increased $\mathrm{H}_{2} \mathrm{O}_{2}$ level stays high in relation to stress situations and the efficiency of the antioxidant response system. Changes in $\mathrm{H}_{2} \mathrm{O}_{2}$ content lead to various effects at the cellular and organism level (physiological and developmental effects); modified after Desikan et al. (2003). 
tion in selected plant tissues. The methods used for $\mathrm{H}_{2} \mathrm{O}_{2}$ determination in plant cells or plant extracts are imperfect and non-specific (Shulaev \& Oliver, 2006). In the literature, the endogenous concentration of $\mathrm{H}_{2} \mathrm{O}_{2}$ is reported to lie in a wide range, ranging from nanomoles to several hundred micromoles of $\mathrm{H}_{2} \mathrm{O}_{2}$ per gram fresh mass (Asada \& Takahashi, 1987; Willekens et al., 1997; Karpinski et al., 1999; Veljovic-Jovanovic et al., 2002). Veljovic-Jovanovic et al. (2002) have shown that substances such as Asc and phenolic compounds present in plant extracts strongly affect the concentration of $\mathrm{H}_{2} \mathrm{O}_{2}$. Nevertheless, it is possible to calculate rates of $\mathrm{H}_{2} \mathrm{O}_{2}$ production in different cell compartments using some experimental data and theoretical estimations (Asada \& Takahashi, 1987; Polle, 2001; Foyer \& Noctor, 2003). It is suggested that the tolerance of plants to high $\mathrm{H}_{2} \mathrm{O}_{2}$ levels is due to the fact that plant antioxidant response systems are designed more for the control of the cellular redox state than for complete elimination of $\mathrm{H}_{2} \mathrm{O}_{2}$. Photo-active chloroplasts are the main suppliers of $\mathrm{H}_{2} \mathrm{O}_{2}$ and it is estimated that the chloroplast/peroxisome system generates about $90 \%$ of the total $\mathrm{H}_{2} \mathrm{O}_{2}$ in the photosynthetically active plant cell (Foyer \& Noctor, 2003). The relative stability and higher concentrations of $\mathrm{H}_{2} \mathrm{O}_{2}$ in plant cells could point to the fact that $\mathrm{H}_{2} \mathrm{O}_{2}$ plays a key role as a signal transduction factor. However, signal molecules are usually present in cells in very low concentrations; the relatively high level of $\mathrm{H}_{2} \mathrm{O}_{2}$ in plant tissues supports the assumption that $\mathrm{H}_{2} \mathrm{O}_{2}$ is not only a signalling molecule, but also plays a key role in primary plant metabolism. Moreover, $\mathrm{H}_{2} \mathrm{O}_{2}$ regulates the expression of various genes, including those encoding antioxidant enzymes and modulators of $\mathrm{H}_{2} \mathrm{O}_{2}$ production (Neill et al., 2002a; 2002b; Geisler et al., 2006). A micro-array study showed that the expression of several hundreds genes was altered in $\mathrm{H}_{2} \mathrm{O}_{2}$-treated Arabidopsis cell cultures, and among them several genes associated with PET chain were repressed (Desikan et al., 2001). $\mathrm{H}_{2} \mathrm{O}_{2} /$ ROS-responsive cis-regulatory elements in gene promoter regions have been identified recently (Geisler et al., 2006). Although $\mathrm{H}_{2} \mathrm{O}_{2}$ is a signal molecule affecting the transcriptome, it is not clear whether $\mathrm{H}_{2} \mathrm{O}_{2}$ is actually the signal per se, or whether oxidation of other molecules by $\mathrm{H}_{2} \mathrm{O}_{2}$ is needed to generate an intracellular signal (Desikan et al., 2003). To date, no $\mathrm{H}_{2} \mathrm{O}_{2}$ receptor has been definitively identified in plants (Foyer \& Noctor, 2003; Geisler et al., 2006). However, such plant genetic systems like NPR1 (non-expresser of pathogen responsive gene 1) and LSD1 (lesion simulating disease response 1), analogous to the $\mathrm{NF}-\kappa \mathrm{B}$ system in animals, could play a role in the $\mathrm{H}_{2} \mathrm{O}_{2}$ sensing mechanism (Mateo et al., 2004; 2006). Specific $\mathrm{H}_{2} \mathrm{O}_{2}$-regulated kinase signalling cascades and transcription factors (trans-elements) have not been identified and characterized yet. It is speculated that soluble thiol-containing low molecular mass compounds (e.g. GSH) or some proteins possessing active cysteine thiols (e.g. GPX) can activate $\mathrm{H}_{2} \mathrm{O}_{2}$ responsive transcription factors (TFs) directly or indirectly. $\mathrm{H}_{2} \mathrm{O}_{2}$ might also activate signalling protein kinases (e.g. mitogen activated protein kinases, MAPK); a protein kinase can phosphorylate a TF, and then the TF interacting with $\mathrm{H}_{2} \mathrm{O}_{2}$-responsive elements regulates the expression of a gene (for a review see: Neill et al., 2002a; Foyer \& Noctor, 2003; Apel \& Hirt, 2004). Candidates for $\mathrm{H}_{2} \mathrm{O}_{2}$-dependent redox regulation are thiol group-containing TRXs. Especially, it could be that the oxidation/reduction cycles of the ferredoxin/TRX system in chloroplasts can regulate the activity of many different enzymes, including those involved in the Calvin cycle (Buchanan \& Balmer, 2005).

Hydrogen peroxide has also been shown to be an intercellular signal mediating systemic acquired resistance (SAR) (e.g. Alvarez et al., 1998) and systemic acquired acclimation (SAA; Karpinski et al., 1999); a role for $\mathrm{H}_{2} \mathrm{O}_{2}$ has also been described in response to wounding (Orozco-Cárdenas \& Ryan, 1999). An important question can be raised here: if $\mathrm{H}_{2} \mathrm{O}_{2}$ is involved in so many diverse responses, how can it be specific? It has been discussed that depending on the site of generation and interaction with specific hormonal compounds, such as salicylic acid (SA), nitric oxide (NO), ethylene, auxins, abscisic acid (ABA) and others, $\mathrm{H}_{2} \mathrm{O}_{2}$ is able to act in a specific manner (Van Breusegem et al., 2001; Neill et al., 2002b; Pastori \& Foyer, 2002; Torres et al., 2006). Especially the interconnections between $\mathrm{H}_{2} \mathrm{O}_{2} / \mathrm{ROS}$ and $\mathrm{NO}$ /reactive nitrogen species (RNS) in the context of plant metabolism are intensively studied (e.g. Yamasaki, 2005).

Hydrogen peroxide under non-stress and stress responses shows tissue-specific localization. The tissue-specific localization of $\mathrm{H}_{2} \mathrm{O}_{2}$ is associated mainly with vascular tissues of leaf veins (OrozcoCárdenas \& Ryan, 1999; Fryer et al., 2003; Mullineaux et al., 2006). Numerous studies demonstrate that $\mathrm{H}_{2} \mathrm{O}_{2}$ is produced in the xylem and phloem (Hérouart et al., 1994; Ogawa et al., 1997; Ros Barceló, 1998; Karpinska et al., 2001; Fryer et al., 2003). Responses of Arabidopsis leaves to light stress have been observed as the accumulation of $\mathrm{H}_{2} \mathrm{O}_{2}$, especially in the vascular bundles (Fryer et al., 2003). Apart from the various enzymes producing $\mathrm{H}_{2} \mathrm{O}_{2}$, such as the oxidases and peroxidases, the localization of $\mathrm{Cu} / \mathrm{Zn}-\mathrm{SOD}$ isoforms in the ECM has been described (Karpinska et al., 2001; Alscher et al., 2002). It has been shown that gene expression and enzyme activity of $\mathrm{Cu} / \mathrm{Zn}$ SOD is linked with both xylem and phloem tissues (Ogawa et al., 1997; Karpinska et al., 2001; Walz et al., 2002). It has also been proposed by Karpinska et 
al. (2001) that $\mathrm{Cu} / \mathrm{Zn}$-SOD isoforms in vascular tissues might act as regulators of $\mathrm{H}_{2} \mathrm{O}_{2}$ pulses, being involved in the transmission of systemic signals in wounding or pathogen responses. Localized cellular responses were also observed by Orozco-Cárdenas and Ryan (1999), Fryer et al. (2003), Chang et al. (2004), and Mateo et al. (2004). On this basis it has been suggested that photo-produced $\mathrm{H}_{2} \mathrm{O}_{2}$ under high light stress is predominantly derived from photosynthetically active bundle sheath cell chloroplasts and that $\mathrm{H}_{2} \mathrm{O}_{2}$ is transported into the transpiration stream in the xylem. A weak point of this hypothesis is the requirement for $\mathrm{H}_{2} \mathrm{O}_{2}$ transport from the chloroplast through the cytosol to the apoplast (Mullineaux et al., 2006). Another offered explanation of the high level of $\mathrm{H}_{2} \mathrm{O}_{2}$ in the leaf venation system is based on the fact that the ECM of the xylem/phloem cell walls is the main donor of $\mathrm{H}_{2} \mathrm{O}_{2}$ required for lignification in the cell wall (Olson \& Varner, 1993; Ros Barceló, 1998). Continuous production and removal of $\mathrm{H}_{2} \mathrm{O}_{2}$ during cell wall synthesis is most likely the reason for its very high steady state concentration in the leaf venation system.

It should be emphasised that the spatial distribution of $\mathrm{H}_{2} \mathrm{O}_{2}$ is not uniform within the whole leaf, but its concentration strongly depends on the type of leaf tissue and environmental conditions. Most studies related to $\mathrm{H}_{2} \mathrm{O}_{2}$ production in plant cells have focused on the photosynthetic activity of the chloroplast, and peroxisomes as the main donors of $\mathrm{H}_{2} \mathrm{O}_{2}$, but much evidence indicates that the ECM also becomes an important source of $\mathrm{H}_{2} \mathrm{O}_{2}$ in plants, especially during plant responses to environmental stress.

\section{$\mathrm{H}_{2} \mathrm{O}_{2}$ signalling during growth and development}

Recently, information on the role of $\mathrm{H}_{2} \mathrm{O}_{2} /$ ROS as signal molecules regulating growth and morphogenesis has emerged, suggesting that $\mathrm{H}_{2} \mathrm{O}_{2}$ is not only a stress signal molecule, but may also be an intrinsic signal in plant growth and development. $\mathrm{H}_{2} \mathrm{O}_{2}$ has also been shown to be involved in differentiation of the cellulose-rich cell wall (Potikha et al., 1999). Recently, it has been demonstrated that diminished extracellular $\mathrm{Cu} / \mathrm{Zn}-\mathrm{SOD}$ expression in poplar trees regulates extracellular $\mathrm{H}_{2} \mathrm{O}_{2}$ level and plant development (Srivastava et al., 2006).

Under specific conditions, certain somatic plant cells are capable of forming embryos following the resumption of cell division activity and totipotency through the developmental pathway of somatic embryogenesis. One possible link between oxidative stress and plant regeneration in tissue cultures could be $\mathrm{H}_{2} \mathrm{O}_{2}$. The specific induction of GPX and GST by $2 \mathrm{mM} \mathrm{H}_{2} \mathrm{O}_{2}$ in cell suspension cultures of soybean and the cross-membrane trafficking of
$\mathrm{H}_{2} \mathrm{O}_{2}$ were the first demonstration of $\mathrm{H}_{2} \mathrm{O}_{2}$-inducible gene expression in plants (Levine et al., 1994). Whereas cell cycle progression is under negative control of ROS, somatic embryogenesis is stimulated by $\mathrm{H}_{2} \mathrm{O}_{2}$ in Lycium barbarum (Cui et al., 1999). A modification in endogenous $\mathrm{H}_{2} \mathrm{O}_{2}$ content was also noted in Mesembryanthemum crystallinum plant tissue culture and was related to the ability of callus tissue to regenerate. The highest $\mathrm{H}_{2} \mathrm{O}_{2}$ concentration was found in callus with regeneration potential (Libik et al., 2005a). Differences in $\mathrm{H}_{2} \mathrm{O}_{2}$ content between rhizogenic and embryogenic calli of $M$. crystallinum were also evident. Root formation was performed by heterotrophic callus with low activity of PSII, while somatic embryos appeared on calli with an autotrophic nature and high activity of PSII (Libik et al., 2005a). These results suggest that differences in oxidative events during morphogenic processes might be linked to photosynthesis accompanying the formation of roots or somatic embryos.

\section{Light and $\mathrm{H}_{2} \mathrm{O}_{2}$ in response to pathogens}

Following pathogen infection, transient $\mathrm{H}_{2} \mathrm{O}_{2} /$ ROS overproduction and accumulation can promote a local defence response connected with NADPH oxidase activation (Keller et al., 1998). The increase of $\mathrm{H}_{2} \mathrm{O}_{2} / \mathrm{ROS}$ levels causes the hypersensitive response (HR) as well, leading to rapid localized cell death at infection sites (lesions), which is a form of programmed cell death (PCD), or can induce SAR (Alvarez et al., 1998; Kuźniak \& Urbanek, 2000; Mateo et al., 2004; Talarczyk \& Hennig, 2001). Recent studies indicated that $\mathrm{H}_{2} \mathrm{O}_{2} /$ ROS-triggered $\mathrm{HR}$ restricted the spread of biotrophs (Hückelhoven \& Kogel, 2003), whereas necrotrophic plant pathogen growth was facilitated (Govrin \& Levine, 2000). In response to pathogens, $\mathrm{H}_{2} \mathrm{O}_{2}$ is able to stimulate cross-linking of cell wall proteins, which reinforces the cell wall, thereby blocking the pathogen spread that occurs upon infection (Brisson et al., 1994). Moreover, it has been found that feruloyl-arabinoxylan trisaccharide in the cell wall can be oxidatively coupled by $\mathrm{H}_{2} \mathrm{O}_{2}$, creating a barrier against pathogens (Encina \& Fry, 2005). It has been shown that CAT activity and hydrogen peroxide level strongly influence local responses of the plant to infection (Talarczyk et al., 2002). The crosstalk between all $\mathrm{H}_{2} \mathrm{O}_{2}$ producing cell compartments that adapts the metabolism to stress conditions is strongly connected to light-dependent photosynthetic processes in the cell (Mateo et al., 2004). According to a traditional point of view, during pathogen resistance responses the primary source of $\mathrm{H}_{2} \mathrm{O}_{2} / \mathrm{ROS}$ is not the chloroplast, but a plasma membrane NADPH oxidase (Apel \& Hirt, 2004), and it has been suggested by others that the photosynthesis and photorespira- 
tion are not likely to be important sources of $\mathrm{H}_{2} \mathrm{O}_{2}$ in defence against pathogens and the hypersensitive disease response. Recent evidence shows that the development of plant resistance to microbial pathogens requires illumination during infection (Mateo et al., 2004; Roberts \& Paul, 2006). In most cases in both resistant and susceptible plant-pathogen interactions, perturbations in photosynthesis, such as the depression of PET chain, reduced $\mathrm{CO}_{2}$ assimilation and decreased stomatal conductance have been observed (for a review see: Bechtold et al., 2005). Moreover, experiments with lesion mimic mutants, which have lesions similar to those formed during $\mathrm{HR}$, showed a link between $\mathrm{H}_{2} \mathrm{O}_{2} /$ ROS produced in chloroplasts and plant stress responses, including pathogen resistance (Karpinski et al., 2003; Mateo et al., 2004; 2006; Bechtold et al., 2005). Additionally, at least part of the pathways involved in the biosynthesis of major defence-related hormones: jasmonic acid (JA), SA and ABA are located in chloroplasts (Karpinski et al., 2003; Roberts \& Paul, 2006). This fact also indicates a role for photosynthesis in both abiotic and biotic stress responses. We know now of a co-ordination of the processes that regulate light acclimation and the establishment of immunity to some pathogens (Bechtold et al., 2005). The above considerations might lead to the suggestion that light acclimatory responses or those to other abiotic stress factors (temperature, relative humidity) will lead to immunity against infection by a pathogen. This was recently confirmed by an analysis of different SA mutants (with deregulated high or low SA levels), which demonstrated that an optimal SA level is required for optimal photosynthesis and that cellular levels of SA, GSH and $\mathrm{H}_{2} \mathrm{O}_{2}$ are physiologically and genetically linked (Mateo et al., 2006).

\section{$\mathrm{H}_{2} \mathrm{O}_{2}$ AND PHOTOSYNTHETIC MODE OF CARBON ASSIMILATION}

As it has been shown above, the PET chain is a driving force leading to $\mathrm{H}_{2} \mathrm{O}_{2}$ production in green plants. Surprisingly, almost no detailed studies focusing on a comparison between $\mathrm{H}_{2} \mathrm{O}_{2}$ production in plants representing the three main modes of $\mathrm{CO}_{2}$ assimilation, i.e. $\mathrm{C}_{3}, \mathrm{C}_{4}$ and Crassulacean acid metabolism (CAM) have been done. Most of the available results describe studies in $C_{3}$ plants (Foyer \& Noctor, 2000; 2003). Li et al. (2001) compared the concentration of $\mathrm{H}_{2} \mathrm{O}_{2}$ in leaves in several species of $\mathrm{C}_{3}, \mathrm{C}_{4}$ and CAM plants, and they showed that the average concentration of $\mathrm{H}_{2} \mathrm{O}_{2}$ in CAM plants is about two-fold higher than in $\mathrm{C}_{3}$ and $\mathrm{C}_{4}$ plants, and $\mathrm{H}_{2} \mathrm{O}_{2}$ concentration does not differ between $\mathrm{C}_{3}$ and $\mathrm{C}_{4}$ plants (Li et al., 2001), nevertheless, more research is re- quired. A lack of other experimental data allows one only to speculate on how much $\mathrm{H}_{2} \mathrm{O}_{2}$ might be produced in $\mathrm{C}_{4}$ and CAM plants in comparison to obligate $\mathrm{C}_{3}$ plants. The general assumption is that photosynthetic $\mathrm{O}_{2}$ uptake, i.e. photoreduction of $\mathrm{O}_{2}$ (the Mehler reaction) and photorespiration, are the main suppliers of $\mathrm{H}_{2} \mathrm{O}_{2}$. According to this assumption, in $\mathrm{C}_{4}$ plants, where photorespiration is strongly reduced, the Mehler reaction should be the more important sink for electrons. A few studies with $\mathrm{C}_{4}$ plants showed that the level of light-dependent $\mathrm{O}_{2}$ uptake is much lower than for $\mathrm{C}_{3}$ plants (Badger et al., 2000), but the question of whether these observations indicate that the $\mathrm{H}_{2} \mathrm{O}_{2}$ concentration is lower in leaves of $\mathrm{C}_{4}$ plants than in $\mathrm{C}_{3}$ plants, needs a more detailed study. In CAM plants $\mathrm{CO}_{2}$ from the atmosphere enters the mesophyll cells at night (Phase I of CAM), and in the cytosol $\mathrm{CO}_{2}$ is fixed to form malic acid in the reaction catalysed by phosphoenolpyruvate carboxylase (PEPC). At the beginning of the day (Phase II of CAM) malate effluxes from the vacuole to the cytosol. In the next step malate is decarboxylated. The decarboxylation takes place predominantly in the middle of the day (Phase III of CAM). During Phase III of CAM the stomata are closed, and this can lead to a parallel increase in both the intercellular partial pressure of $\mathrm{O}_{2}\left(\mathrm{p}_{\mathrm{i}} \mathrm{O}_{2}\right)$ and $\mathrm{CO}_{2}$ $\left(\mathrm{p}_{\mathrm{i}} \mathrm{CO}_{2}\right)$ in planta. An increased $\mathrm{O}_{2}$ level in Phase III behind closed stomata can promote overproduction of $\mathrm{H}_{2} \mathrm{O}_{2} / \mathrm{ROS}$ in CAM plants (Miszalski et al., 1998; Lüttge, 2002; 2004). In recent years, the intermediate $\mathrm{C}_{3}$-CAM plant $M$. crystallinum has become a very useful model for studying antioxidant response systems in both modes of photosynthesis: $C_{3}$ and CAM (Miszalski et al., 1998; 2001; Niewiadomska et al., 1999; 2004; Broetto et al., 2002; Ślesak et al., 2002; 2003; Libik et al., 2005b; Borland et al., 2006). In previous work we have demonstrated that $\mathrm{H}_{2} \mathrm{O}_{2}$ is photo-produced in $M$. crystallinum leaves as a result of the PET chain activity in chloroplasts. Our data suggested that the redox status of the PQ pool and photo-produced $\mathrm{H}_{2} \mathrm{O}_{2}$ are involved in the $\mathrm{C}_{3}$-CAM transition in $M$. crystallinum (Ślesak et al., 2003). Some oxidative stress factors different from $\mathrm{H}_{2} \mathrm{O}_{2}$, such as ozone (Niewiadomska et al., 2002; Hurst et al., 2004; Borland et al., 2006) and sulphur dioxide (Surówka et al., 2007), did not evoke CAM in M. crystallinum leaves. However, they induced some of the CAMrelated enzymes. Moreover, experiments with $M$. crystallinum suggest that CAM appears to lower ROS production (oxidative stress) in plants exposed to extended periods of salinity (Borland et al., 2006). Nevertheless, the question of how $\mathrm{H}_{2} \mathrm{O}_{2} /$ ROS are involved in the CAM mode of photosynthesis needs more detailed studies. 


\section{$\mathrm{H}_{2} \mathrm{O}_{2}$ AND THE EVOLUTION OF PSII}

It has been suggested that $\mathrm{H}_{2} \mathrm{O}_{2}$ could be an early electron donor to PSII (for a review see: Olson \& Blankenship, 2004). Blankenship and Hartman (1998) proposed that $\mathrm{H}_{2} \mathrm{O}_{2}$ may have been a transitional donor and that the present oxygen-evolving complex (OEC) may be structurally related to Mn-containing catalases. The oxidation of $\mathrm{H}_{2} \mathrm{O}_{2}$ in PSII might be expected to be similar to the oxidation reaction catalyzed by CAT, which decomposes $\mathrm{H}_{2} \mathrm{O}_{2}$ to water and oxygen. Mn-catalases have a binuclear Mn center that is structurally similar to half of the proposed tetranuclear center of the OEC (Dismukes, 1996; Pace \& Åhrling, 2004) and that under certain conditions the OEC can act as a catalase. It cannot be excluded that the PSII reaction centre-like complex associated with a Mn-catalase might have been able to evolve $\mathrm{O}_{2}$ using $\mathrm{H}_{2} \mathrm{O}_{2}$ as electron donor (Olson \& Blankenship, 2004). When Blankenship and Hartman (1998) made their proposal, there was no evidence for a significant concentration of $\mathrm{H}_{2} \mathrm{O}_{2}$ ever existing on the Earth, but recently it has been shown that pyrite-induced $\mathrm{H}_{2} \mathrm{O}_{2}$ formation from $\mathrm{H}_{2} \mathrm{O}$ is possible without molecular oxygen, thus it could have taken place in the absence of oxygen on the young Earth (Borda et al., 2001). However, experiments with $\mathrm{H}_{2} \mathrm{O}_{2}$-treated cyanobacteria cells have shown inhibition of OEC, suggesting that $\mathrm{H}_{2} \mathrm{O}_{2}$ could not be a physiological electron donor for PSII (Samuilov et al., 2001). The hypothesis about a role of $\mathrm{H}_{2} \mathrm{O}_{2}$ as a driving force of OEC evolution requires changes, in our opinion, concerning the state of the Earth surface many million years ago; whether the surface was more oxidised or reduced is still under debate (Lane, 2002). It is known that $\mathrm{H}_{2} \mathrm{O}_{2}$ is present in huge amounts on the surface of Mars (Hartman \& McKay, 1995; Encrenaz et al., 2004). It might not be excluded that the surface of the Earth was also loaded with an adequate amount of $\mathrm{H}_{2} \mathrm{O}_{2}$ derived from photochemical processes about 3.5 billion years ago.

\section{CONCLUSIONS}

The main sources of $\mathrm{H}_{2} \mathrm{O}_{2}$ in the plant cell under steady-state conditions are the light-driven processes of photosynthesis and photorespiration. Hydrogen peroxide is a crucial component involved in the regulation of plant metabolism, defence and acclimatory processes, and gene expression. It also appears to coordinate plant development and the cell cycle. $\mathrm{H}_{2} \mathrm{O}_{2}$ levels increase in stress situations and its concentration in plant tissues is usually higher than in animal tissues. Specific mechanisms of $\mathrm{H}_{2} \mathrm{O}_{2}$ generation play an important role in diversification of $\mathrm{H}_{2} \mathrm{O}_{2}$ signalling. Hydrogen peroxide regulates other hormonal responses in plants, therefore it can play an imperative role as a 'master hormone'. Genetic systems controlling $\mathrm{H}_{2} \mathrm{O}_{2}$ signalling in plants have been suggested (Mateo et al., 2004; 2006).

\section{Acknowledgements}

We are grateful to Lionel Scott for comments on the manuscript.

This work was supported by the Ministry of Science and Higher Education (Poland) grant Nos. N301 075 31/2414, N303 083 31/2685, R1204502, and by the Swedish Research Council (VR).

\section{REFERENCES}

Alscher RG, Erturk N, Heath LS (2002) Role of superoxide dismutases (SODs) in controlling oxidative stress in plants. J Exp Bot 53: 1331-1341.

Alvarez ME, Pennell RI, Meijer P-J, Ishikawa A, Dixon RA, Lamb C (1998) Reactive oxygen intermediates mediate a systemic signal network in the establishment of plant immunity. Cell 92: 773-784.

Apel K, Hirt H (2004) Reactive oxygen species: metabolism, oxidative stress, and signal transduction. Annu Rev Plant Biol 55: 373-399.

Asada K (1999) The water-water cycle in chloroplasts: scavenging of active oxygens and dissipation of excess photons. Anпu Rev Plant Physiol Plant Mol Biol 50: 601-639.

Asada K, Takahashi M (1987) Production and scavenging of active oxygen in photosynthesis. In Photoinhibition. Kyle DJ, Osmond BJ, Arntzen CJ, eds, pp 227-287. Elsevier, Amsterdam.

Badger MR, Von Caemmerer S, Ruuska S, Nakano H (2000) Electron flow to oxygen in higher plants and algae: rates and control of direct photoreduction (Mehler reaction) and rubisco oxygenase. Phil Trans $R$ Soc Lond B 355: 1433-1446.

Ball L, Accotto GP, Bechtold U, Creissen G, Funck D, Jimenez A, Kular B, Leyland N, Mejia-Carranza J, Reynolds H, Karpinski S, Mullineaux PM (2004) Evidence for a direct link between glutathione biosynthesis and stress defense gene expression in Arabidopsis. Plant Cell 16: $2448-2462$.

Bartosz G (1997) Oxidative stress in plants. Acta Physiol Plant 19: 47-64.

Bechtold U, Karpinski S, Mullineaux PM (2005) The influence of the light environment and photosynthesis on oxidative signalling responses in plant-biotrophic pathogen interactions. Plant Cell Environ 28: 1046-1055.

Blankenship RE, Hartman H (1998) The origin and evolution of oxygenic photosynthesis. Trends Biochem Sci 23: 94-97.

Bolwell GP, Bindschedler LV, Blee KA, Butt VS, Davies DR, Gardner SL, Gerrish C, Minibayeva F (2002) The apoplastic oxidative burst in response to biotic stress in plants: a three-component system. J Exp Bot 53: 1367-1376.

Borda MJ, Elsetinow AR, Schooen AR, Strongin DR (2001) Pyrite-induced hydrogen peroxide formation as a driving force in the evolution of photosynthetic organisms on an early Earth. Astrobiology 1: 283-288.

Borland A, Elliot S, Patterson S, Taybi T, Cushman J, Pater B, Barnes J (2006) Are the metabolic components of 
crassulacean acid metabolism up-regulated in response to an increase in oxidative burden? J Exp Bot 57: 319328.

Brisson LE, Tenhaken R, Lamb C (1994) Function of oxidative cross-linking of cell wall structural proteins in plant disease resistance. Plant Cell 6: 1703-1712.

Broetto F, Lüttge U, Ratajczak R (2002) Influence of light intensity and salt-treatment on mode of photosynthesis and enzymes of the antioxidative response system of Mesembryanthemum crystallinum. Funct Plant Biol 29: 13-23.

Buchanan BB, Balmer Y (2005) Redox regulation: a broadening horizon. Annu Rev Plant Biol 56: 187-220.

Chang CCC, Ball L, Fryer MJ, Baker NR, Karpinski S, Mullineaux PM (2004) Induction of ascorbate peroxidase 2 expression in wounded Arabidopsis leaves does not involve known wound-signalling pathways but is associated with changes in photosynthesis. Plant $J$ 38: 499-511.

Cornic G, Fresneau C (2002) Photosynthetic carbon reduction and carbon oxidation cycles are the main electron sinks for photosystem II activity during a mild drought. Ann Bot 89: 887-894.

Creissen G, Firmin J, Fryer M, Kular B, Leyland N, Reynolds H, Pastori G, Wellburn F, Baker N, Wellburn A, Mullineaux P (1999) Elevated glutathione biosynthetic capacity in the chloroplasts of transgenic tobacco plants paradoxically causes increased oxidative stress. Plant Cell 11: 1277-1292.

Cui K, Xing G, Liu X, Wang Y (1999) Effect of hydrogen peroxide on somatic embryogenesis of Lycium barbarum L. Plant Sci 146: 9-16.

Dat J, Vandenabeele S, Vranová E, Van Montagu M, Inzé D, Breusegem F (2000) Dual action of the active oxygen species during plant stress responses. CMLS Cell Mol Life Sci 57: 779-795.

Demmig-Adams B, Adams III WW (1996) The role of xanthophyll cycle carotenoids in the protection of photosynthesis. Trends Plant Sci 1: 21-26.

Desikan R, Mackerness A-H S, Hancock JT, Neill SJ (2001) Regulation of the Arabidopsis transcriptome by oxidative stress. Plant Physiol 127: 159-172.

Desikan R, Hancock JT, Neill SJ (2003) Oxidative stress signalling. Top Curr Genet 4: 129-149.

Dismukes GC (1996) Manganese enzymes with binuclear active sites. Chem Rev 96: 2909-2926.

Dixon RA, Lamb CJ (1990) Molecular communication in interactions between plants and microbial pathogens. Annu Rev Plant Physiol Plant Mol Biol 41: 339-367.

Dixon DP, Lapthorn A, Edwards R (2002) Plant glutathione transferases. Genome Biol 3: 3004-3008.

Edwards EA, Enard C, Creissen GP, Mullineaux PM (1994) Synthesis and properties of glutathione reductase in stressed peas. Planta 192: 137-143.

Encina A, Fry SC (2005) Oxidative coupling of feruloylarabinoxylan trisaccharide (FAXX) in the walls of living maize cells requires endogenous hydrogen peroxide and is controlled by a low- $M_{\mathrm{r}}$ apoplastic inhibitor. Planta 223: 77-89.

Encrenaz Th, Bézard B, Greathouse TK, Richter MJ, Lacy JH, Atreya SK, Wong AS, Lebonnois S, Lefèvre F, Forget $F$ (2004) Hydrogen peroxide on Mars: evidence for spatial and seasonal variations. Icarus 170: 424-429.

Feierabend J, Schaan C, Hertwig B (1992) Photoinactivation of catalase occurs under both high- and low-temperature stress conditions and accompanies photoinhibition of photosystem II. Plant Physiol 100: 1554-1561.
Fine PL, Frasch WD (1992) The oxygen-evolving complex requires chloride to prevent hydrogen peroxide formation. Biochemistry 31: 12204-12210.

Foyer Ch, Noctor G (2000) Oxygen processing in photosynthesis: regulation and signalling. New Phytol 146: 359-388.

Foyer Ch, Noctor G (2003) Redox sensing and signalling associated with reactive oxygen in chloroplasts, peroxisomes and mitochondria. Physiol Plant 119: 355-364.

Frugoli JA, Zhong HH, Nuccio ML, McCourt P, McPeek MA, Thomas TL, McClung CR (1996) Catalase is encoded by multigene family in Arabidopsis thaliana (L.) Heynh. Plant Physiol 112: 327-336.

Fryer MJ, Ball L, Oxborough K, Karpinski S, Mullineaux PM, Baker NR (2003) Control of ascorbate peroxidase 2 expression by hydrogen peroxide and leaf water status during excess light stress reveals a functional organisation of Arabidopsis leaves. Plant J 33: 691-705.

Geisler M, Kleczkowski LA, Karpinski S (2006) A universal algorithm for genome-wide in silico identification of biologically significant gene promoter putative cisregulatory-elements; identification of new elements for reactive oxygen species and sucrose signaling in Arabidopsis. Plant J 45: 384-398.

Govrin EM, Levine A (2000) The hypersensitive response facilitates plant infection by the necrotrophic pathogen Botrytis cinerea. Curr Biol 10: 751-757.

Halliwell B, Gutteridge JMC (1999) The chemistry of free radicals and related 'reactive species'. In Free radicals in biology and medicine. pp 36-104. Oxford University Press, Oxford.

Halliwell B (2006) Reactive species and antioxidants. Redox biology is a fundamental theme of aerobic life. Plant Physiol 141: 312-322.

Hartman H, McKay CP (1995) Oxygenic photosynthesis and the oxidation state of Mars. Planet Space Sci 43: 123-128.

Henzler T, Steudel E (2000) Transport and metabolic degradation of hydrogen peroxide in Chara corallina: model calculations and measurements with the pressure probe suggest transport of $\mathrm{H}_{2} \mathrm{O}_{2}$ across water channels. J Exp Bot 51: 2053-2066.

Hérouart D, Van Montagu M, Inzé D (1994) Developmental and environmental regulation of the Nicotiana plumbaginifolia cytosolic $\mathrm{Cu} / \mathrm{Zn}$-superoxide dismutase promoter in transgenic tobacco. Plant Physiol 104: 873-880.

Hertwig B, Streb P, Fieirabend J (1992) Light dependence of catalase synthesis and degradation in leaves and the influence of interfering stress conditions. Plant Physiol 100: 1547-1553.

Horling F, König J, Dietz K-J (2002) Type II peroxiredoxin C, a member of the peroxiredoxin family of Arabidopsis thaliana: its expression and activity in comparison with other peroxiredoxins. Plant Physiol Biochem 40: 491-499.

Hung S-H, Yu C-W, Lin CH (2005) Hydrogen peroxide function as a stress signal in plants. Bot Bull Acad Sin 46: $1-10$.

Hurst AC, Grams TEE, Ratajczak R (2004) Effects of salinity, high irradiance, ozone, and ethylene on mode of photosynthesis, oxidative stress and oxidative damage in the $\mathrm{C}_{3} / \mathrm{CAM}$ intermediate plant Mesembryanthemum crystallinum L. Plant Cell Environ 27: 187- 197.

Hückelhoven R, Kogel K-H (2003) Reactive oxygen intermediates in plant-microbe interactions: who is who in powdery mildew resistance? Planta 216: 891-902.

Inzé D, Van Montagu M (1995) Oxidative stress in plants. Curr Biol 6: 153-158.

Juszczuk IM, Rychter AM (2003) Alternative oxidase in higher plants. Acta Biochim Polon 50: 1257-1271. 
Kaiser WM (1979) Reversible inhibition of the Calvin cycle and activation of oxidative pentose phosphate cycle in isolated intact chloroplasts by hydrogen peroxide. Planta 145: 377-382.

Kacperska A (2004) Sensor types in signal transduction pathways in plant cells responding to abiotic stressors: do they depend on stress intensity? Physiol Plant 122: 159-168.

Karpinska B, Wingsle G, Karpinski S (2000) Antagonistic effects of hydrogen peroxide and glutathione on acclimation to excess excitation energy in Arabidopsis. IUBMB Life 50: 21-26.

Karpinska B, Karlsson M, Schinkel H, Streller S, Süss K-H, Melzer M, Wingsle G (2001) A novel superoxide dismutase with a high isoelectric point in higher plants. Expression, regulation, and protein localization. Plant Physiol 126: 1668-1677.

Karpinski S, Escobar C, Karpinska B, Creissen G, Mullineaux PM (1997) Photosynthetic electron transport regulates the expression of cytosolic ascorbate peroxidase genes in Arabidopsis during excess light stress. Plant Cell 9: 627-640.

Karpinski S, Reynolds H, Karpinska B, Wingsle G, Creissen G, Mullineaux P (1999) Systemic signalling and acclimation in response to excess excitation energy in Arabidopsis. Science 284: 654-657.

Karpinski S, Gabryś H, Mateo A, Karpinska B, Mullineaux PM (2003) Light perception in plant disease defence signalling. Curr Opin Plant Biol 6: 390-396.

Keller T, Damude HG, Werner D, Doerner P, Dixon RA, Lamb C (1998) A plant homolog of the neutrophil NADPH oxidase gp91-phox subunit gene encodes a plasma membrane protein with $\mathrm{Ca}^{2+}$ binding motifs. Plant Cell 10: 255-266.

Kozaki A, Takeba G (1996) Photorespiration protects $C_{3}$ plants from photooxidation. Nature 384: 557-560.

Kuźniak E, Urbanek H (2000) The involvement of hydrogen peroxide in plant responses to stresses. Acta Physiol Plant 22: 195-203.

Lane BG (1994) Oxalate, germin, and the extracellular matrix of higher plants. FASEB J 8: 294-301.

Lane N (2002) Oxygen. The molecule that made the world. Oxford University Press, Oxford.

Levine A, Tenhaken R, Dixon R, Lamb C (1994) $\mathrm{H}_{2} \mathrm{O}_{2}$ from the oxidative burst orchestrates the plant hypersensitive disease resistance. Annu Rev Plant Physiol 121: 245-257.

Li J, Zhao X, Matsui S (2001) Hydrogen peroxide contents and activities of antioxidative enzymes among $\mathrm{C}_{3}, \mathrm{C}_{4}$ and CAM plants. J Japan Soc Hort Sci 70: 747-752.

Libik M, Konieczny R, Pater B, Ślesak I, Miszalski Z (2005a) Differences in the activities of some antioxidant enzymes and in $\mathrm{H}_{2} \mathrm{O}_{2}$ content during rhizogenesis and somatic embryogenesis in callus cultures of the ice plant. Plant Cell Rep 23: 834-841.

Libik M, Konieczny R, Surówka E, Miszalski Z (2005b) Superoxide dismutase activity in organs of Mesembryanthemum crystallinum L. at different stages of CAM development. Acta Biol Cracov Ser Bot 47: 199-204.

Logan BA, Kornyeyev D, Hardison J, Holaday AS (2006) The role of antioxidant enzymes in photoprotection. Photosynth Res 88: 119-132.

Lüttge U (2002) $\mathrm{CO}_{2}$-concentrating: consequences in crassulacean acid metabolism. J Exp Bot 53: 2131-2142.

Lüttge U (2004) Ecophysiology of crassulacean acid metabolism (CAM). Ann Bot 93: 629-652.

Mahalingam R, Federoff N (2003) Stress response, cell death and signalling: the many faces of reactive oxygen species. Physiol Plant 119: 56-68.
Mateo A, Mühlenbock P, Restérucci C, Chi-Chang C, Miszalski Z, Karpinska B, Parker JE, Mullineaux PM, Karpinski S (2004) LESION SIMULATING DISEASE 1 required for acclimation to conditions that promote excess excitation energy. Plant Physiol 136: 2818-2830.

Mateo A, Funck D, Mühlenbock P, Kular B, Mullineaux PM, Karpinski S (2006) Controlled levels of salicylic acid are required for optimal photosynthesis and redox homeostasis. J Exp Bot 57: 1795-1807.

Matés JM (2000) Effects of antioxidant enzymes in the molecular control of reactive oxygen species toxicology. Toxicology 153: 83-104.

Mehler AH (1951) Studies on reactions of illuminated chloroplasts. II Stimulation and inhibition of the reaction with molecular oxygen. Arch Biochem Biophys 33: 339-351.

Miszalski Z, Ślesak I, Niewiadomska E, Baczek-Kwinta R, Lüttge U, Ratajczak R (1998) Subcellular localization and stress responses of superoxide dismutase isoforms from leaves in the $\mathrm{C}_{3}$-CAM intermediate halophyte Mesembryanthemum crystallinum L. Plant Cell Environ 21: 169-179.

Miszalski Z, Niewiadomska E, Ślesak I, Lüttge U, Kluge M, Ratajczak R (2001) The effect of irradiation on carboxylating/decarboxylating enzymes and fumarase activities in Mesembryanthemum crystallinum L. exposed to salinity stress. Plant Biol 3: 17-23.

Mittler R (2002) Oxidative stress, antioxidants and stress tolerance. Trends Plant Sci 7: 405-410.

Mittler R (2004) Reactive oxygen gene network of plants. Trends Plant Sci 9: 490-498.

Møller IM (2001) Plant mitochondria and oxidative stress: electron transport, NADPH turnover, and metabolism of reactive oxygen species. Annu Rev Plant Physiol Plant Mol Biol 52: 561-591.

Mullineaux PM, Karpinski S (2002) Signal transduction in response to excess light: getting out of the chloroplast. Curr Opin Plant Biol 5: 43-48.

Mullineaux PM, Karpinski S, Jiménez A, Cleary SP, Robinson C, Creissen GP (1998) Identification of cDNAs encoding plastid-targeted glutathione peroxidase. Plant J 13: 375-379.

Mullineaux P, Ball L, Escobar C, Karpinska B, Creissen G, Karpinski S (2000) Are diverse signalling pathways integrated in the regulation of Arabidopsis antioxidant defence gene expression in response to excess excitation energy. Phil Trans $R$ Soc Lond B 355: 1531-1540.

Mullineaux PM, Karpinski S, Baker NR (2006) Spatial dependence for hydrogen peroxide-directed signalling in light-stressed plants. Plant Physiol 141: 346-350.

Neill S, Desikan R, Hancock J (2002a) Hydrogen peroxide signalling. Curr Opin Plant Biol 5: 388-395.

Neill S, Desikan R, Clarke A, Hurst RD, Hancock J (2002b) Hydrogen peroxide and nitric oxide as signalling molecules in plants. J Exp Bot 53: 1237-1247.

Niewiadomska E, Miszalski Z, Ślesak I, Ratajczak R (1999) Catalase activity during $\mathrm{C}_{3}$-CAM transition in Mesembryanthemum crystallinum L. leaves. Free Radic Res 31: S251-256.

Niewiadomska E, Pater B, Miszalski Z (2002) Does ozone induce a $\mathrm{C}_{3}$-CAM transition in Mesembryanthemum crystallinum leaves? Phyton (Horn, Austria) 42c: 69-78.

Niewiadomska E, Karpinska B, Romanowska E, Ślesak I, Karpinski S (2004) A salinity-induced $\mathrm{C}_{3}$-CAM transition increases energy conservation in the halophyte Mesembryanthemum crystallinum L. Plant Cell Physiol 45: 789-794. 
Noctor G, Foyer CH (1998) Ascorbate and glutathione: keeping active oxygen under control. Annu Rev Plant Physiol Plant Mol Biol 49: 249-279.

Noctor G, Arisi ACM, Jouanin L, Foyer CH (1999) Photorespiratory glycine enhances glutathione accumulation in both the chloroplastic and cytosolic compartments. I Exp Bot 50: 1157-1167.

Ogawa K, Kanematsu S, Asada K (1997) Generation of superoxide anion and localization of $\mathrm{CuZn}$-superoxide dismutase in vascular tissue of spinach hypocotyls: their association with lignification. Plant Cell Physiol 38: $1118-1126$.

Olson JM, Blankenship RE (2004) Thinking about the evolution of photosynthesis. Photosynth Res 80: 373-396.

Olson PD, Varner JE (1993) Hydrogen peroxide and lignification. Plant Cell 4: 887-892.

Orozco-Cárdenas ML, Ryan CA (1999) Hydrogen peroxide is generated systemically in plant leaves by wounding and systemin via the octadecanoid pathway. Proc Natl Acad Sci USA 96: 6553-6557.

Pace RJ, Åhrling K (2004) Water oxidation in PSII-H atom abstraction revisited. Biochim Biophys Acta 1655: 172178.

Pastori GM, Foyer CH (2002) Common components, networks, and pathways of cross-tolerance to stress. The central role of "redox" and abscisic acid-mediated controls. Plant Physiol 129: 460-468.

Polle A (2001) Dissecting the superoxide dismutase-ascorbate-glutathione-pathway in chloroplasts by metabolic modelling. Computer simulations as a step toward flux analysis. Plant Physiol 126: 445-462.

Potikha TS, Collins CC, Johnson DI, Delmer DP, Levine A (1999) The involvement of hydrogen peroxide in the differentiation of secondary walls in cotton fibers. Plant Physiol 119: 849-858.

Prasad TK, Anderson MD, Martin BA, Stewart CR (1994) Evidence for chilling-induced oxidative stress in maize seedlings and regulatory role of hydrogen peroxide. Plant Cell 6: 65-74.

Rhoads DM, Umbach AL, Subbaiah CC, Siedow JN (2006) Mitochondrial reactive oxygen species. Contribution to oxidative stress and interorganellar signalling. Plant Physiol 141: 357-366.

Roberts MR, Paul ND (2006) Seduced by the dark side: integrating molecular and ecological perspectives on the influence of light on plant defence against pests and pathogens. New Phytol 170: 677-699.

Ros Barceló A (1998) Hydrogen peroxide production is a general property of the lignifying xylem from vascular plants. Ann Bot 82: 97-103.

Samuilov VD, Timofeev KN, Sinitsyn SV, Bezryadnov DV (2001) $\mathrm{H}_{2} \mathrm{O}_{2}$-induced inhibition of photosynthetic $\mathrm{O}_{2}$ evolution by Anabaena variabilis cells. Biochemistry (Moscow) 69: 926-933.

Schmidt M, Dehne S, Feierabend J (2002) Post-transcriptional mechanisms control catalase synthesis during its light-induced turnover in rye leaves through the availability of the hemin cofactor and reversible changes of the translation efficiency of mRNA. Plant J 31: 601-613.

Shulaev V, Oliver DJ (2006) Metabolic and proteomic markers for oxidative stress. New tools for reactive oxygen species research. Plant Physiol 141: 367-372.

Smirnoff N (1996) The function and metabolism of ascorbic acid in plants. Ann Bot 78: 661-669.

Srivastava V, Schinkel H, Witzell J, Hertzberg H, Torp M, Srivastava KM, Karpinska B, Melzer M, Wingsle G (2006) Down-regulation of high isoelectric point extracellular superoxide dismutase mediates alterations in reactive oxygen species metabolism and developmental disturbances in hybrid aspen. Plant J, in press.

Surówka E, Karolewski P, Niewiadomska E, Libik M, Miszalski Z (2007) Antioxidative response of Mesembryanthemum crystallinum plants to exogenous $\mathrm{SO}_{2}$ application. Plant Sci 172: 76-84.

Svedružić D, Jónsson S, Toyota CG, Reinhardt LA, Ricagno S, Lindquist Y, Richards NGJ (2005) The enzymes of oxalate metabolism: unexpected structures and mechanisms. Arch Biochem Biophys 433: 176-192.

Ślesak I, Miszalski Z, Karpinska B, Niewiadomska E, Ratajczak R, Karpinski S (2002) Redox control of oxidative stress responses in the $\mathrm{C}_{3}$-CAM intermediate plant Mesembryanthemum crystallinum. Plant Physiol Biochem 40: 669-677.

Ślesak I, Karpinska B, Surówka E, Miszalski Z, Karpinski S (2003) Redox changes in the chloroplast and hydrogen peroxide are essential for regulation of $\mathrm{C}_{3}$-CAM transition and photooxidative stress responses in the facultative CAM plant Mesembryanthemum crystallinum L. Plant Cell Physiol 44: 573-581.

Talarczyk A, Hennig J (2001) Early defence responses in plants infected with pathogenic organisms. Cell Biol Mol Lett 6: 955-970.

Talarczyk A, Krzymowska M, Borucki W, Hennig J (2002) Effect of yeast CTA1 gene expression on response of tobacco plants to tobacco mosaic virus infection. Plant Physiol 129: 1032-1044.

Torres MA, Jones JDG, Dangl JL (2006) Reactive oxygen species signalling in response to pathogens. Plant Physiol 141: 373-378.

Van Breusegem F, Vranová E, Dat JF, Inzé D (2001) The role of active oxygen species in plant signal transduction. Plant Sci 161: 405-414.

Van Lis R, Atteia A (2004) Control of mitochondrial function via photosynthetic redox signals. Photosynth Res 79: 133-148.

Veljovic-Jovanovic S, Noctor G, Foyer CH (2002) Are leaf hydrogen peroxide concentrations commonly overestimated? The potential influence of artefactual interference by tissue phenolics and ascorbate. Plant Physiol Biochem 40: 501-507.

Vranová E, Inzé D, Van Breusegem F (2002) Signal transduction during oxidative stress. J Exp Bot 53: 12271236.

Walz C, Juenger M, Schad M, Kehr J (2002) Evidence for the presence and activity of a complete antioxidant defence system in mature sieve tubes. Plant J 31: 189-197.

Willekens H, Chamnongpol S, Davey M, Schraudner M, Langebartels C, Van Montagu M, Inzé D, Van Camp W (1997) Catalase is a sink for $\mathrm{H}_{2} \mathrm{O}_{2}$ and indispensable for stress defence in $\mathrm{C}_{3}$ plants. $E M B O \mathrm{~J}$ 16: 4806-4816.

Wingler A, Lea PJ, Quick WP, Leegood RC (2000) Photorespiration: metabolic pathways and their role in stress protection. Phil Trans $R$ Soc Lond B 355: 1517-1529.

Wingsle G, Karpinski S (1996) Differential redox regulation by glutathione of glutathione reductase and $\mathrm{CuZn} \mathrm{su-}$ peroxide dismutase genes expression in Pinus sylvestris (L.) needles. Planta 198: 151-157.

Wojtaszek P (1997) Oxidative burst: an early plant response to pathogen infection. Biochem J 322: 681-692.

Yamasaki H (2005) The NO world for plants: achieving balance in an open system. Plant Cell Environ 28: 7884.

Yu C-W, Murphy TM, Lin C-H (2003) Hydrogen peroxide-induced chilling tolerance in mung beans mediated through ABA-independent glutathione accumulation. Funct Plant Biol 30: 955-963. 